\title{
DOMINANT FACTORS AFFECTING CAPITAL REALIZATION IN SOUTHEAST SULAWESI
}

\author{
Muhamad Armawaddin ${ }^{1}$, Ahmad $^{2}$ \\ Department Economic Dvelopment, Faculty Economic and Business, \\ Universty of Halu Oleo \\ Email: 1adiox68@gmail.com, ${ }^{2}$ ahmad@uho.ac.id
}

\begin{abstract}
This study aims to determine the dominant factors that affect the realization of capital expenditure in districts/cities in Southeast Sulawesi. This type of data used is secondary data on local revenue, equity funds, personnel expenditures, gross regional domestic product, residual funding, population and capital expenditures during 2010-2016. The analysis uses regression analysis of panel data from 12 districts / cities by Ordinary Least Square (OLS) method. The result of the research shows that the dominant factors affecting capital expenditure realization is balance fund. The other result is PAD, personnel expenditure, GRDP which have a significant effect on capital expenditure realization, while the population is not significant. SILPA has significant effect to capital expenditure with partial regression test but not significant with multiple regression test.
\end{abstract}

Keywords: capital expenditure realization, panel data model

\section{INTRODUCTION}

Regional spending is defined as all regional liabilities which its value reduces net worth in a certain period. Funding of mandatory governmental affairs related to minimum service standards is a priority of local spending. Management of local finance should not make it a burden for the community, but the local government and the community should be empowered to cooperate in managing its regional affairs. The problem of regional financial management according to Madiasmo (2004) can be overcome if local government is able to execute management role optimally and the role of policy instrument. Taking role as a policy instrument, local government must be efficient in carrying out its functions and roles, and as a management instrument, local budgets must be able to accommodate various aspirations and initiatives of the community (Madiasmo, 2004). 
The challenge of local government in the era of autonomy is how regions are able to improve and manage the potentials and sources of indigenous wealth to improve public services by providing facilities and infrastructure, as well as regional infrastructure. The realization of all that is contained in the regional development plan allocated in the form of capital expenditure.

With regard to the governance of capital expenditure according to Madiasmo (2004), government is expected to improve welfare and service to the community. Basically, capital expenditure is sub item of regional expenditure which is sourced from regional income that is Pendapatan Asli Daerah (PAD), balance fund (DAU, DAK, DBH) and other valid regional income. Therefore, the optimization of potential revenue by regulating the proportion of capital expenditure allocation can develop productive sectors they have.

According to Nordiawan (2006), Capital Expenditures are government expenditures that generate certain fixed assets. Another definition is according to
Government Regulation of the Republic of Indonesia Number 71 Year 2010 that Capital expenditure is the expenditure of the budget for the acquisition of fixed assets and other assets that provide benefits over one accounting period. Capital expenditures can be land, buildings and buildings, equipment, intangible assets. The priority of capital expenditure allocation is intended for the development of facilities and infrastructure directly related to the improvement of basic services to the community. Its budgeting must meet the needs of the community with efficient, effective, economical and transparent principles.

Capital expenditure budgeting for purchases / multiplication of fixed assets / intangible assets that have a useful life of more than 12 months is used in government activities and meets the minimum limit. Any costs associated with the expenditure of assets with the needs of more than 12 months or 1 year with funds derived from the APBD.

As what has been pointed out that the source of capital expenditure financing is sourced from local revenue. Revenue from the region 
itself comes from its own region (PAD) and assistance from the central government (fiscal balance transfer) and other sources of income other than those two sources. Based on these statements, it can be interpreted that between PAD and equity funds are mutually correlated.

PAD correlated with capital expenditure empirically has been proven by Febriana and Praptoyo (2015), Farel (2015), Afkarina and Hermanto (2017), Fauzia and Riharjo (2017) and Sugiyanta (2016), and Kurniati (2017) which concluded that PAD have a significant and positive influence on capital expenditure. These results indicate that changes in capital expenditure can be explained by changes in PAD itself. The higher the value of PAD collected by the local government, the higher the realization of regional government capital expenditure. Therefore, the hypothesis of this research is that PAD has significant effect on realization of capital expenditure of district / city in Southeast Sulawesi.

Furthermore, fiscal balance transfers are also correlated with capital expenditures empirically proven by Febriana and Praptoyo
(2015) and Afkarina and Hermanto (2017): the influence of positive and significant equity funds (DAU) on capital expenditures; Fauzia and Riharjo (2017): the influence of positive and significant balance funds on capital expenditures; These results indicate that changes in capital expenditures can be explained by changes in fiscal balance transfers (especially DAU) itself. The higher the value of fiscal balance transfers allocated by the central government, the higher the realization of regional government capital expenditure. However, in some empirical studies, it is found that the fiscal balance transfers of DAK and DBH have no significant effect on capital expenditures (Febriana and Praptoyo, 2015 and Kurniati, 2017, Sugiyanta, 2016). However, theoretically, the districts are still dominantly relying on central government funding for development financing (Kuncoro, 2004 and Ndadari and Adi, 2006), then this hypothesis suggests that fiscal balance transfers significantly influence the realization of district / city in Southeast Sulawesi.

Moreover, this study conducts hypothesis testing on the influence of 
personnel expenditure, Budget Financing (SiLPA), GRDP, and population as an important factors in determining the amount of capital expenditure realization. Associated with employee spending estimates correlated with capital expenditure, it has been empirically proven by Kurniati (2017) and Sugiyanta (2016) who found that personnel expenditure has a significant effect on capital expenditure. Theoretically, it is stated that personnel expenditure is a sub item of the same regional expenditure with capital expenditure so the relationship between the two variables is expected to be negative. This means that the higher the allocation of personnel expenditure, the lower the allocation of capital expenditure or vice versa. In this study, it is proposed the hypothesis that PAD has a significant effect on the realization of capital spending of districts / cities in Southeast Sulawesi.

The correlation of GRDP and SILPA with capital expenditure in this study refers to Farel's (2015) and Sugiyanta (2016) studies which conclude that GRDP and SILPA have a positive and significant effect on capital expenditure. GRDP is the value of goods and services produced by district / city every year. The higher the GRDP value, the higher the regional income. The increasing of local revenue gives a positive impact on capital expenditure because the source of financing is from regional income. Related to the correlation with SILPA, the amount of SiLPA has an impact on the increase of budget in the following year assuming that the SILPA value is positive. Conversely, if SILPA value is negative it will impact on the reduction of budget in the next year or delayed implementation of regional expenditure including capital expenditure. In this research, the hypothesis proposed is that GRDP and SILPA have significant effect on realization of capital expenditure of district / city in Southeast Sulawesi.

The next is correlation between population and capital expenditure. As explained earlier that capital expenditure is the procurement or purchase of facilities, and infrastructure for the community. Population growth does not affect the realization of capital expenditures directly due to the factor of inaction. 
This statement is empirically evidenced by Pupiwati (2017) which concludes that the number of residents has no significant effect on capital expenditure. In this research, the hypothesis proposed is that the number of population has no significant effect on the realization of capital expenditure of districts / cities in Southeast Sulawesi.

Related to the realization of capital expenditure, according to Sugiyono (2004), it has been regulated by the Central Government, namely in the range of $22 \%-29 \%$ of total regional expenditure from 2009 to 2013 (Sugiono, 2014). Therefore, it is expected that local governments can optimize the target capital expenditure through development programs that touch directly to the interests of the community.

Table1. Proportion of capital expenditure realization to district / city expenditure 2016-2017

\begin{tabular}{cccc}
\hline Year & Expenditure & $\begin{array}{c}\text { Capital } \\
\text { Expenditure }\end{array}$ & Proportion \\
\hline 2010 & 6.41 & 1.55 & $24.2 \%$ \\
2011 & 7.5 & 1.81 & $24.1 \%$ \\
2012 & 8.75 & 1.86 & $21.3 \%$ \\
2013 & 10.03 & 2.68 & $26.7 \%$ \\
2014 & 11.59 & 3.21 & $27.7 \%$ \\
2015 & 14.24 & 4.42 & $31.0 \%$ \\
2016 & 16.97 & 5.39 & $31.8 \%$ \\
\hline \multicolumn{4}{l}{ Source: DJPK.KemenKeu RI (2017) }
\end{tabular}

The phenomenon of capital expenditure realization of district / city expenditure realization in Southeast Sulawesi 2010-2016 (Table 1) shows the proportion of capital expenditure realization that varies. In 2010-2014, districts / cities have not reached the target of capital expenditure realization and only in 2015-2016 reach the target. In order to achieve the target of capital expenditure realization, the consideration of PAD factor, Fiscal balance transfer, SiLPA, GRDP, Personnel expenditure and residents is very important to know by the government in Southeast Sulawesi so that development planning can really accommodate community interest as mandated in the implementation of autonomy area.

In association with that statement, it has been empirically proved that PAD and fiscal balance transfers (DAU) have a significant effect on capital expenditure (Febriana and Praptoyo, 2015). Local Own Revenue (PAD), Gross Regional Domestic Product (GRDP), and Budget Financing Surplus (SiLPA) have positive and significant effect to capital expenditure in Bogor 
Regency (Farel, 2015). Furthermore, Afkarina and Hermanto (2017) found that Local Original Income and Equilibrium Fund (DAU) have a positive effect on Capital Expenditure either partially or simultaneously. Local Original Income, Fiscal balance transfer and Budget Financing have a positive effect on Capital Expenditures (Fauzia and Riharjo, 2017). Kurniati (2017) and Sugiyanta (2016) found that local revenue and personnel expenditures have an effect on capital expenditure allocation. On the other hand, Kurniati (2017), Febriana and Praptoyo (2015) and Sugiyanta (2016) also found that fiscal balance transfers (DBH and DAK), and the remaining budgetary calculations do not affect the allocation of capital expenditures.

Referring to the contradictions of the research results that have been put forward, the research on the dominant factors affecting capital expenditure is very important to do especially in Southeast Sulawesi. The model of capital expenditure predictors model in this study is the result of elaboration of the research model conducted by Afkarina and
Hermanto (2017), Fauzia and Riharjo (2017), Kurniati (2017), Febriana and Praptoyo (2015), and Farel (2015), ie: PAD, Fiscal balance transfer, SiLPA, GRDP, Population, and Personnel expenditure. The dominant factors influence the capital expenditure of districts / cities in Southeast Sulawesi by referring to the tests conducted by Murniasih and Mulyadi (2011) by comparing the statistic $t$ regression partial $t$ value with $t$ statistic multiple regression.

The objectives of this study are (1) to examine and analyze the effect of PAD, fiscal balance transfers, personnel expenditure, GRDP, SiLPA and residents on capital expenditures realization; (2) to determine the dominant factors affecting the realization of district / city capital expenditure in Southeast Sulawesi.

\section{METHODS}

This study uses panel data with Ordinary Least Square model (OLS) by observing variables affecting capital expenditure realization of 12 districts / cities during 2010-2016. The only consideration of using 12 out of 17 
districts / cities is because the other 5

districts / cities are just expansion between 2013 and 2015 so that the data required by this research is not yet available. The analysis steps determining the dominant factors that affect the realization of capital expenditure are:

Partial regression is used to determine the effect of individual from each variable of PAD, Fiscal balance transfer, Personnel expenditure, GRDP, SiLPA, and Number of population to capital expenditure realization. From this regression, it will get the value of t-stat of each variable from the test results of individual influences. The partial and multiple regression models are:

$$
\begin{aligned}
& \mathrm{BM}_{\mathrm{it}}=\hat{\mathrm{a}}_{0}+\beta_{1} \mathrm{PAD}_{\mathrm{it}}+\mu_{\mathrm{it}} \\
& \mathrm{BM}_{\mathrm{it}}=\beta_{0}+\beta_{1} \mathrm{DP}_{\mathrm{it}}+\mu_{\mathrm{it}} \\
& \mathrm{BM}_{\mathrm{it}}=\beta_{0}+\beta_{1} \mathrm{BP}_{\mathrm{it}}+\mu_{\mathrm{it}} \\
& \mathrm{BM}_{\mathrm{it}}=\beta_{0}+\beta_{1} \mathrm{PDRB}_{\mathrm{it}}+\mu_{\mathrm{it}} \\
& \mathrm{BM}_{\mathrm{it}}=\beta_{0}+\beta_{1} \mathrm{SiLPA}_{\mathrm{it}}+\mu_{\mathrm{it}} \\
& \mathrm{BM}_{\mathrm{it}}=\beta_{0}+\beta_{1} \mathrm{PDDK}_{\mathrm{it}}+\mu_{\mathrm{it}} \\
& \mathrm{BM}_{\mathrm{it}}=\beta_{0}+\beta_{1} \mathrm{PAD}_{\mathrm{it}}+\beta_{2 \mathrm{t}} \mathrm{DP}_{\mathrm{it}}+ \\
& \beta_{3} \mathrm{BP}_{\mathrm{it}}+\beta_{4} \mathrm{PDRB}_{\mathrm{it}}+\beta_{5} \mathrm{SILPa}_{\mathrm{it}}+ \\
& \beta_{6} \mathrm{PDDK}_{\mathrm{it}}+\mu_{\mathrm{it}}(7)
\end{aligned}
$$

\begin{tabular}{|c|c|}
\hline $\mathrm{PAD}_{\text {it }}$ & $\begin{array}{l}\text { O Original Local } \\
\text { Government Revenue of } \\
\text { district/city-i year-t }\end{array}$ \\
\hline $\mathrm{DP}_{\mathrm{it}}$ & $\begin{array}{l}\text { : Fiscal Balance Transfer } \\
\text { of district/city-i year- } t\end{array}$ \\
\hline $\mathrm{BP}_{\mathrm{it}}$ & $\begin{array}{l}\text { : Personnel Expenditure of } \\
\text { district/city-i year-t }\end{array}$ \\
\hline $\mathrm{PDRB}_{\text {it }}$ & $\begin{array}{l}\text { Produk domestic } \\
\text { Regional Bruto constant } \\
2010 \text { of district/city-i } \\
\text { year-t }\end{array}$ \\
\hline $\operatorname{SiLPA}_{\mathrm{it}}$ & $\begin{array}{l}\text { SiLPA of district/city-i } \\
\text { year-t }\end{array}$ \\
\hline $\mathrm{PDDK}_{\mathrm{it}}$ & $\begin{array}{l}\text { : population of district / } \\
\text { city-i year-t }\end{array}$ \\
\hline$u_{i t}$ & : error term \\
\hline
\end{tabular}

with:

$$
\begin{array}{ll}
\mathrm{BM}_{\mathrm{it}}: & \text { Capital expenditure of } \\
& \text { district / city- } \mathrm{i} \text { year- } \mathrm{t} \\
\beta_{0} & : \text { Constant }
\end{array}
$$

Multiple regression is used to determine the simultaneous effect of PAD, Fiscal balance transfers, Personnel Expenditures, GRDP, SiLPA, and population on capital expenditure realization. From this regression, it will get the value of $t$ stat of each variable from the simultaneous effect test results.

To determine which factors dominantly determine the realization of district / city capital expenditure in Southeast Sulawesi by referring to Murniasih and Mulyadi (2011) testing, we compare the difference 
between t-stat of each factor from partial regression with multiple regression that has significant effect. The dominant factor affecting capital expenditure realization is the factor with positive t-stat.

\section{RESULT AND DISCUSSION}

The result of partial regression analysis (Table 2), PAD, fiscal balance transfer, personnel Expenditure, SiLPA, GRDP and Population have positive and significant effect to the change of regional expenditure. PAD parameter coefficients, fiscal balance transfer, personnel Expenditure, SiLPA, GRDP and Population are positive.

Table 2. Partial Regression Model

\begin{tabular}{|c|c|c|c|c|}
\hline \multicolumn{5}{|c|}{ Dependent Variable: Caoital Expenditure } \\
\hline \multirow{2}{*}{$\begin{array}{l}\text { Independent } \\
\text { Variable }\end{array}$} & \multirow{2}{*}{ Coefficient } & \multicolumn{2}{|c|}{ Adjusted T- } & \multirow{2}{*}{$\begin{array}{l}\text { F- } \\
\text { Statistic }\end{array}$} \\
\hline & & $\mathrm{R}^{2}$ & Statistic & \\
\hline PAD & $1.423 * * *$ & 0.339 & 6.596 & 43.501 \\
\hline \multicolumn{5}{|l|}{ Fiscal } \\
\hline Balance & $0.292 * * *$ & 0.441 & 8.16 & 66.577 \\
\hline \multicolumn{5}{|l|}{ Transfer } \\
\hline $\begin{array}{l}\text { Personnel } \\
\text { Expenditure }\end{array}$ & $0.0961^{*}$ & 0.022 & 1.704 & 2.904 \\
\hline SiLPA & $0.237 * *$ & 0.047 & 2.252 & 5.069 \\
\hline PDRB & $6.951 * * *$ & 0.111 & 3.374 & 11.383 \\
\hline Population & 0.099 & 0.001 & 1.028 & 1.057 \\
\hline
\end{tabular}

It means that any increase in PAD, fiscal balance transfer, personnel Expenditure, SiLPA, GRDP and Population will lead to an increase in district capital expenditure in Southeast Sulawesi.

The partial regression results are in line with the results of multiple linear regression (Table 3), where PAD, Fiscal Balance Transfer, Personnel Expenditures, SiLPA, GRDP and Population simultaneously affect the realization of capital expenditures.

Table 3. Multiple Regression Model

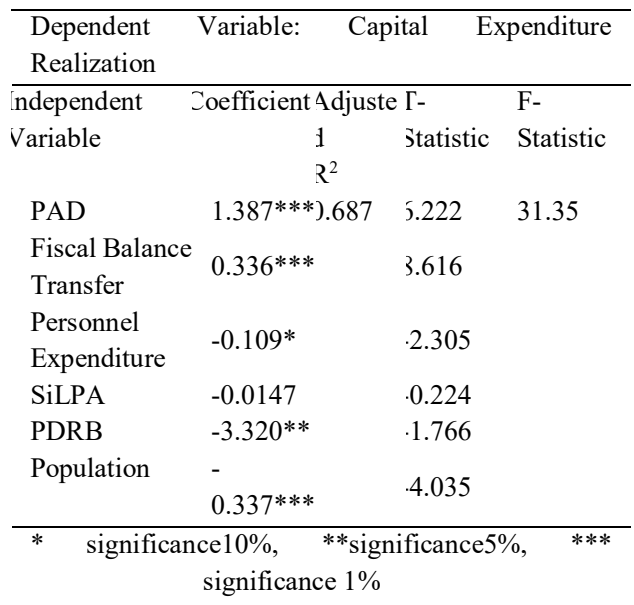

However, SiLPA variable individually has no significant effect on capital expenditure realization and this result is different with partial regression result where SiLPA has significant effect on capital expenditure realization. Changes in 
capital expenditures are caused by PAD, Fiscal balance transfer, personnel Expenditures, SiLPA, GRDP and Population amounted to $68.7 \%$ (R2 adjusted). This means that the model's ability to explain changes in regional expenditure variables is $68.7 \%$ and the rest of $32.3 \%$ is explained by other variables not included in the model. The results of this study are in line with the researches conducted by Afkarina and Hermanto (2017), Fauzia and Riharjo (2017), Kurniati (2017), Febriana and Praptoyo (2015), and Farel (2015). Related to the influence of individual SiLPA variable that is not significant to capital expenditure realization, this research is in line with research by Afkarina and Hermanto (2017) and Febriana and Praptoyo (2015) which also found that SiLPA has no significant effect on capital expenditure realization.

Based on the result of partial regression (Table 2) and multiple regression (Table 3), there are different results of individual test. From the results of partial regression, it found that population is not significant while in the multiple regressio, it has significant effect on the realization of capital expenditure. Similarly, SiLPA with partial regression significantly effexr on capital expenditure realization but it has different result in multiple regression which it has no significant effect on capital expenditure realization. The inconsistency of the test results of these two variables is likely to be due to SiLPA's still encounter deficit in some districts / cities. Thus, affecting the realization of capital expenditure in the next year and also from the side of the population, caused by the uneven distribution of population in districts / cities in Southeast Sulawesi so that the provision of facilities and infrastructure can not be reached by the local government.

Based on the results of partial and multiple regression, it is found that the test results are inconsistent, SiLPA and population. Therefore, the requirement for testing of dominant factors affecting capital expenditure realization must be significant on partial and multiple regression analysis, then the two factors are not included in the testing of dominant factors affecting capital expenditure realization. Thus, the factors to be 
tested are only four factors, namely

PAD, Fiscal balance transfer, personnel Expenditures, and GRDP.

Table 4. Dominant Factor

\begin{tabular}{lccc}
\hline $\begin{array}{c}\text { Independe } \\
\text { nt } \\
\text { Variables }\end{array}$ & $\begin{array}{c}\text { T- } \\
\text { Statistic } \\
\text { Partial } \\
\text { Regressio } \\
\mathrm{n}\end{array}$ & $\begin{array}{c}\text { T-Statistic } \\
\text { Simultaneo } \\
\text { us } \\
\text { Regression }\end{array}$ & $\begin{array}{c}\text { Differen } \\
\text { ce }\end{array}$ \\
\hline $\begin{array}{l}\text { PAD } \\
\text { Fiscal }\end{array}$ & 6.596 & 6.222 & -0.374 \\
$\begin{array}{l}\text { Balance } \\
\text { Transfer }\end{array}$ & 8.16 & 8.616 & 0.456 \\
$\begin{array}{l}\text { Personnel } \\
\text { Expenditur } \\
\text { e }\end{array}$ & 1.704 & -2.305 & -4.009 \\
GRDP & 3.374 & -1.766 & -5.14 \\
\hline
\end{tabular}

Based on the calculations in

Table 4, fiscal balance transfer t-stat increases 0.456 , while the statistical value of $\mathrm{PAD}$, personnel Expenditure and GRDP decrease respectively by $0.374,4.009$ and 5.140. Thus, it can be concluded that the effect of DAU on capital expenditure in the same year is significant or in other words that DAU is the most dominant factor affecting realization of district / city capital expenditure in Southeast Sulawesi in 2010-2016 period.

\section{CONCLUSION}

Based on the analysis and discussion above, it can be concluded that the dominant factor affecting the realization of district / city capital expenditure in Southeast Sulawesi in 2010-2016 is the balance fund as evidenced by the positive difference between the $t$ value of statistical test result of multiple regression test with partial regression. Other results show that PAD, personnel expenditure, GRDP have significant effect on capital expenditure realization by partial and multiple regression test, while population is not significant to the realization of capital expenditure. SILPA has significant effect to capital expenditure with partial regression test but not significant with multiple regression test.

This study has not included all the variables that affect the realization of capital expenditure such as local financial performance. Subsequent research should perform testing by including these variables as moderator. Because this variable is influenced by PAD. Fiscal balance transfer also affects capital expenditure realization.

\section{REFERENCE}

Afkarina, Zia. Dan Hermanto, Suwardi Bambang. 2017. Pengaruh PAD, DAU, SILPA Dan Luas Wilayah Terhadap Belanja Modal. Jurnal Ilmu dan Riset Akuntansi Volume 6, Nomor 8, Agustus 2017.

Farel, Rully. 2015. Faktor-Faktor Yang Mempengaruhi 
Dominant Factors Affecting Capital.

(Muhamad Armawaddin ${ }^{1}$, Ahmad $^{2}$ )

$\begin{array}{llr}\text { Belanja Modal } & \begin{array}{r}\text { Di } \\ \text { Kabupaten }\end{array} \\ \text { Signifikan Vol. } 4 & \text { Nogor. } 2 \\ \text { Oktober 2015 } & & \end{array}$

Fauzia, Farah Wahyu dan Riharjo, Ikhsan Budi. 2017. FaktorFaktor Yang Mempengaruhi Belanja Modal (Penelitian pada Pemerintah Kabupaten / kota Di Jawa Timur). Jurnal Ilmu dan Riset Akuntansi. Volume 6, Nomor 6, Juni 2017.

Febriana Imas Sherli dan Praptoyo, Sugeng. 2015. Analisis Faktor-Faktor Yang Mempengaruhi Belanja Modal Pada Provinsi Jawa Timur. Jurnal Ilmu \& Riset Akuntansi. Vol. 4 No. 9 (2015)

Kuncoro, H. 2004. Pengaruh Transfer Antar Pemerintah Pada Kinerja Fiskal Peme-rintah Daerah Kota Dan Kabupaten Di Indonesia. Jurnal Ekonomi Pembangunan Vol. 9

Kurniati, Putri Tri. 2017. Analisis Faktor-Faktor Yang BerpePuspitawati, Gina. 2017. Pengaruh Pendapatan Asli Daerah, Jumlah Penduduk Dan Pdrb Terhadap Belanja Modal (Penelitian Empiris Pemerin-tahan Kabupaten \& Kota di NTB 2010-2015). SKRIPSI. Fakultas Ekonomi Dan Bisnis Program Penelitian Ekonomi Keuangan Dan Perbankan Islam Universitas Muhammadiyah Yogyakarta. Diakses tanggal 21 Februari 2018: http://repository.umy. ac.id/handle/123456789/157 64. ngaruh Terhadap Alokasi Belanja Modal (Penelitian Empiris pada Pemerintah Daerah Kabupaten dan Kota di Jawa Timur Periode Tahun 2010-2014)

Madiasmo. 2004. Otonomi dan Manajemen Keuangan Daerah. Yogyakarta: Andi.

Murniasih, Erny dan Mulyadi, M. Syarif. 2011. Pengaruh Transfer Pemerintah Pusat terhadap Perilaku Fiskal Pemerintah Daerah di Provinsi Kalimantan Timur. Jurnal Ekonomi dan Pembangunan Indonesia. Vol. 12 No.1, Juli 2011: 5671.

Ndadari, L.W. dan Adi, P.H. 2008. Perilaku Asymetris Peme=rintah Daerah Terhadap Transfer Pemerintah Pusat. The $2^{\text {nd }}$ National Conference UKWMS. Surabaya.

Nordiawan, D. 2006. Akuntansi Sektor Publik. Penerbit Salemba Empat. Jakarta.

Sugiyanta. 2016. Analisis Belanja Modal Dan Faktor-Faktor Yang Mempengaruhinya Pada Pemerintah Kabupaten / kota Di Indonesia. Jurnal Akuntansi Universitas Jember - Vol. 14 No. 1 Juni 2016.

Sugiono, S. 2014. Pengaruh Moderasi Pendapatan Asli Daerah terhadap Hubungan Belanja Modal dan Kemandirian Keuangan Daerah. Jurnal Akuntansi Unesa, 2 (3): 1-2. 